\title{
ANALISIS KEMAMPUAN TABUNGAN PETANI UNTUK MENANGGUNG BIAYA PEREMAJAAN KEBUN KARETNYA DI MUSI BANYUASIN SUMATERA SELATAN
}

\author{
Oleh : \\ Tirta Jaya Jenahar dan S.K Hildayanti \\ Dosen Program Magister Manajemen UIGM Palembang \\ Email : proftirta57@yahoo.com
}

\begin{abstract}
Abstrak
Penelitian ini bertujuan untuk menganalisis kemampuan tabungan petani untuk menanggung biaya peremajaan karetnya. Pengumpulan data primer secara acak dilakukan pada bulan Agustus sampai Nopember 2015 dengan mewawancara sebanyak 120 petani responden pada di Kabupaten Musi Banyuasin Sumatera Selatan.

Hasil penelitian menunjukan bahwa tabungan petani tradisional dan maju mampu membiayai peremajaan kebun karetnya karena hanya sekitar $8 \%$ dari tabungan petani per tahun
\end{abstract}

Kata Kunci; Kata kunci : Analisis ekonomi,tabungan petani.

\section{PENDAHULUAN}

Perkebunan karet alam di Sumatera Selatan sangat strategis karena provinsi ini pada tahun 2012 merupakan daerah penghasil utama karet alam di Indonesia dengan total produksi 576.676 ton atau $35,66 \%$ dari produksi karet Indonesia. Kontribusi karet alam terhadap Produk Domestik Regional Bruto (PDRB) Sumatera Selatan sebesar Rp 2.861 juta atau $9,07 \%$ dari total PDRB dan dari produksi karet tersebut sebanyak $62 \%$ diekspor yang merupakan masukan devisa negara sebesar US \$280,4 juta (34\%) dari ekspor Sumatera Selatan juga sebagai sumber kebutuhan hidup sekitar 429.846 KK atau sekitar 2 juta penduduk Sumatera Selatan (Dinas Perkebunan Provinsi Sumatera Selatan, 2012).

Luas areal, produksi perkebunan karet rakyat dan petani karet di Sumatera Selatan dapat dilihat pada Tabel 1.

Tabel. 1. Luas Areal, Produksi Perkebunan Karet Rakyat Dan Petani Karet Di Sumsel Th.2014

\begin{tabular}{|c|c|c|c|c|c|c|c|c|c|c|c|}
\hline \multirow{2}{*}{ No } & \multirow{2}{*}{ Kabupaten / Kota } & \multicolumn{5}{|c|}{ Luas Areal (ha) } & \multicolumn{3}{|c|}{ Produksi (ton) } & \multicolumn{2}{|l|}{ Petani } \\
\hline & & TBM & TM & TT/TR & Jumlah & $\%$ & Produksi & $\%$ & Rata-Rata & (KK) & $\%$ \\
\hline 1. & Musi Banyuasin & 37.118 & 95.102 & 21.149 & 153.369 & 17,98 & 74.281 & 14,87 & 0,64 & 84.462 & 19,65 \\
\hline 2. & Ogan Komering llir & 38.911 & 61.913 & 14.898 & 115.723 & 13,57 & 65.752 & 13,16 & 0,66 & 32.179 & 7,49 \\
\hline 3. & Ogan Komering Ulu & 25.848 & 49.894 & 6.039 & 82.052 & 9,62 & 99.669 & 19,95 & 0,81 & 45.807 & 10,66 \\
\hline 4. & Muara Enim & 57.254 & 87.437 & 16.552 & 161.243 & 18,91 & 45.383 & 9,08 & 0,58 & 120.932 & 28,13 \\
\hline 5. & Lahat & 2.716 & 11.074 & 3.498 & 17.288 & 2,03 & 22.249 & 4,45 & 0,45 & 9.101 & 2,12 \\
\hline 6. & Musi Rawas & 27.400 & 137.254 & 51.898 & 216.552 & 25,39 & 96.917 & 19,40 & 0,69 & 96.317 & 22,41 \\
\hline 7. & Banyuasin & 18.461 & 51.989 & 11.383 & 81.833 & 9,60 & 74.281 & 14,87 & 0,68 & 31.828 & 7,40 \\
\hline 8. & Pagar Alam & 44 & 28 & 0 & 72 & 0,01 & 67 & 0,01 & 0,45 & 59 & 0,01 \\
\hline 9. & Prabumulih & 4.015 & 11.286 & 2.653 & 17.954 & 2,11 & 17.954 & 3,59 & 0,58 & 9.161 & 2,13 \\
\hline 10 & Lubuk Linggau & 861 & 4.450 & 1.415 & 6.727 & 0,79 & 3.123 & 0,63 & 0,68 & & 0,00 \\
\hline & Jumlah & 212.629 & 510.428 & 129.757 & 852.815 & 100 & 499.676 & 100 & 0,64 & 429.846 & 100 \\
\hline
\end{tabular}

Sumber : Laporan Tahunan Dinas Perkebunan Provinsi Sumatera Selatan Tahun 2014

* Statistik Perkebunan Indonesia Tahun 2014 
Pengembangan pembangunan karet rakyat di Sumatera Selatan dari berbagai proyek pemerintah berbantuan (Proyek Perusahaan Inti Rakyat dan Unit Pelaksana Proyek, Parsial) selama 25 tahun (1997/1998 s/d 2002) tercatat mencapai seluas 224.721 ha atau sekitar 8.988 ha/tahun. Dengan asumsi proyek tersebut masih berjalan dengan laju pertumbuhan yang sama maka untuk meremajakan karet tua/rusak yang luasnya 129.757 ha akan dibutuhkan waktu sekitar 14 tahun. Padahal setiap tahun akan ada sekitar 2,5\% luasan tanaman muda yang akan memasuki masa peremajaan.

Sejak tahun 1992-2003 Pemerintah Daerah di Sumatera Selatan telah mengimplemen-tasikan peremajaan karet swadaya/partisipatif seluas 1.248 ha melalui fasilitas bantuan Peme-rintah Daerah kabupaten yaitu Kabupaten Muara Enim seluas 724 ha mencakup 362 petani, Kabupaten Musi Banyuasin pilot proyek 24 ha, kebun entris 4,2 ha dan pelatihan 240 petani, dan Kabupaten Ogan Komering Ulu seluas 500 ha, kebun entris 24 ha, pelatihan 120 petani (Supriadi dan Nancy, 2004).

Pemerintah Daerah Sumatera Selatan telah memperhitungkan biaya untuk meremajakan tanaman karet seluas 100.000 ha yaitu sekitar Rp 776,25 milyar yang diprogramkan selama kurun waktu 10 tahun (2005-2014) (Dinas Perkebunan Provinsi Sumatera Selatan, 2004). Apabila keseluruhan dana tersebut dibebankan kepada anggaran pemerintah daerah tentu akan memberatkan. Oleh karena itu alokasi tenaga kerja keluarga petani perlu didorong secara opti-mal dan difasilitasi untuk meremajakan tanaman karetnya secara mandiri. Fasilitas yang dapat diberikan pemerintah daerah antara lain bantuan parsial (bahan tanaman karet), pembinaan teknis dan penyuluhan (Supriadi et al., 2001).

Dari harapan dan kenyataan tersebut dapat disimpulkan bahwa yang menjadi masalah pokok adalah berapa besar kemampuan tabungan petani untuk menanggung biaya investasi peremajaan kebun karetnya secara mandiri? Penelitian ini secara umum bertujuan untuk Menganalisis besarnya kemampuan tabungan petani untuk menanggung biaya peremajaan kebun karetnya secara mandiri.

Hasil penelitian ini diharapkan berguna untuk menjelaskan karakteristik ekonomi rumah tangga petani karet rakyat yang berkaitan kegiatan pendapatan, biaya dan tabungan keluarga petani karet rakyat.

\section{Tinjauan Pustaka Dan Model Pendekatan}

Peremajaan yang dilakukan secara teratur akan memberikan manfaat yang sangat besar seperti yang dikemukakan oleh Wargadipura (1978) yaitu berupa terbukanya kesempatan untuk menggunakan ; (1) bahan tanaman baru berupa klon bermutu tinggi hasil pemuliaan dan seleksi terakhir, (2) hasil terbaru dalam bidang bercocok tanam, (3) hasil penelitian yang lebih efisien dalam manajemen. Menurut Supriadi et al. (1999), upaya peremajaan karet dengan menerapkan teknologi maju secara swadaya sebenarnya telah dilakukan oleh sebagian petani, namun pelaksanaannya relatif lambat dan tingkat keberhasilannya rendah, karena menghadapi berbagai kendala.

Hasil penelitian Supriadi et al. (2001), di Kabupaten Musi Banyuasin Sumatera Selatan mengungkapkan bahwa sebagian besar pengeluaran keluarga tani karet (82$83 \%$ ) digunakan untuk kebutuhan 
konsumsi pokok. Pengeluaran untuk pemeliharaan kebun sangat kecil, yaitu sekitar 3\% di Kecamatan Sungai Keruh dan kurang dari 1\% di Kecamatan Babat Toman. Alasan pokok rendahnya pengeluaran untuk investasi kebun ini adalah minimnya pendapatan petani di
6.934.958,33 per ha per tahun. Hasil penelitian Gunawan dan Supriadi (1988), yang dilakukan di Proyek Pengembangan Karet Rakyat-Unit Prabumulih, Sumatera Selatan menunjukkan bahwa pe-tani mengutamakan penggunaan pendapatannya untuk konsumsi pangan 61 persen.
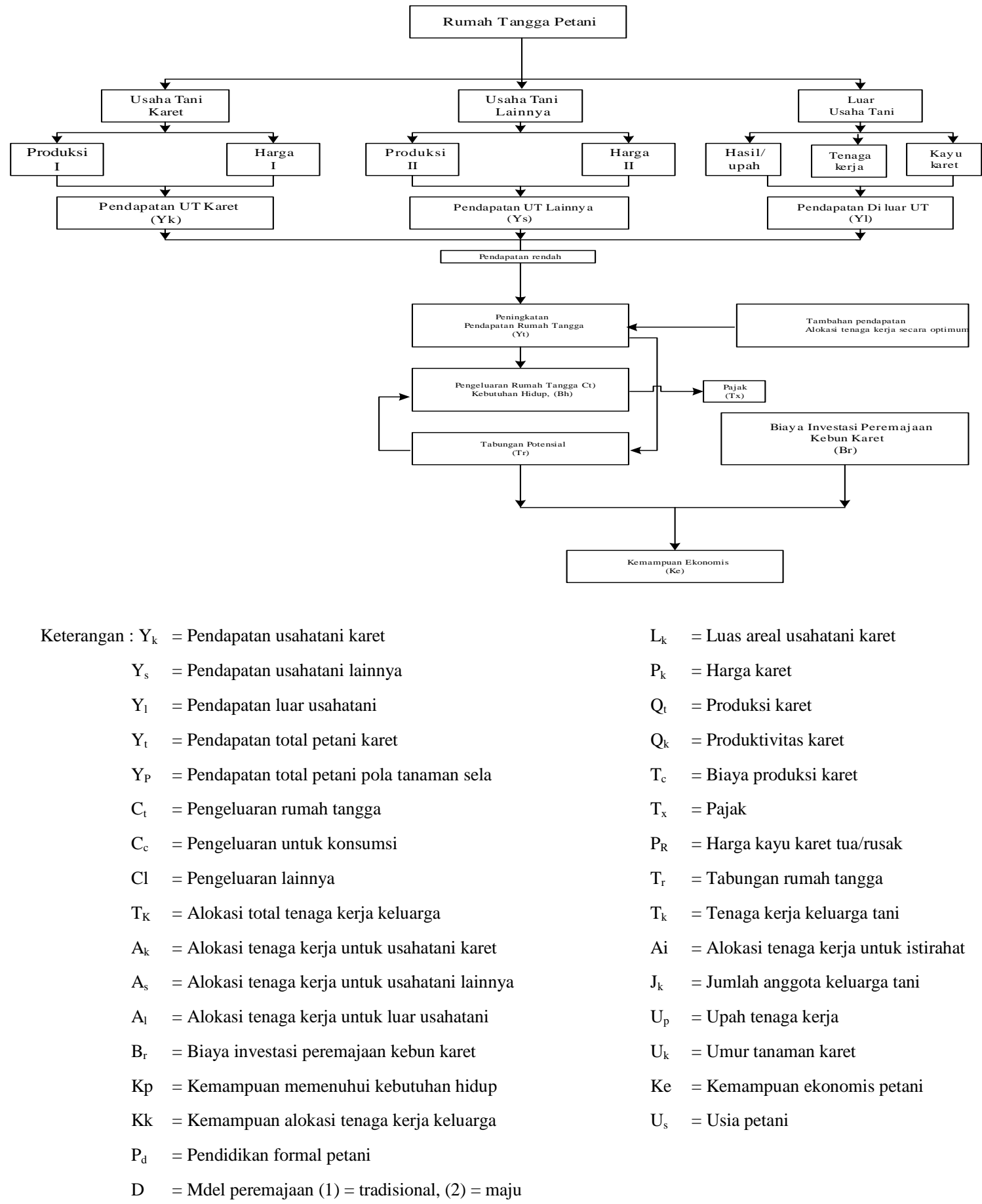

Gambar 1. Kerangka Pemikiran Penelitian Analisis Tenaga Kerja Keluarga

Petani Dalam Peremajaan Kebun Karetnya 
Pada Gambar 1 dapat dijelaskan bahwa pendapatan usahatani karet (Yk), pendapatan usahatani lainnya (Ys) dan pendapatan petani dari luar usahatani (Yl) rendah, yang pada gilir-annya akan mengakibatkan pendapatan rumah tangga petani (Yt) rendah dan tabungan rumah tangga (Tr) rendah sehingga pada akhirnya menyebabkan kemampuan usahatani petani rendah dan berakibat petani tidak dapat menanggung biaya investasi peremajaan kebun karetnya se-cara mandiri.

Upaya untuk meningkatkan kemampuan tabungan petani dapat dilakukan dengan meng-alokasikan tenaga kerja keluarga secara optimum sehingga pendapatan keluarga meningkat dan diharapkan tabungan rumah tangga petani meningkat sehingga kemampuan usahatani pe-tani meningkat. Apabila kemampuan usahatani tinggi maka peremajaan karet akan dapat di-laksanakan.

Berdasarkan tujuan penelitian yang akan dicapai maka diajukan hipotesis : " Diduga kemampuan tabungan petani tidak mampu untuk menanggung biaya peremajaan kebun karetnya secara mandiri”.

Batasan operasional dari beberapa istilah sebagai berikut :

1. Tanaman karet tua atau rusak adalah tanaman karet yang berumur lebih dari umur eko-nomis (>25 tahun), sedangkan tanaman karet rusak sebagai akibat kurang pemeliharaan dan penyadapan yang berat.

2. Rumah tangga keluarga dalam arti ekonomi adalah sekelompok orang yang hidup dalam satu rumah mengelola ekonomi keluarga, pembagian kerja, pendapatan, konsumsi, jenis produksi dan jasa yang dihasilkan.

3. Petani karet dalam penelitian ini adalah petani pekebun rakyat yang memiliki kebun karet dan menggarapnya sendiri sebagai mata pencarian pokok.

4. Petani tradisional adalah petani pekebun rakyat yang mengggunakan bahan tanaman non klon atau seedling.

5. Petani maju adalah petani pekebun rakyat yang menggunakan bahan tanaman klon unggul-an.
6. Peremajaan tanaman karet adalah penanaman tanaman karet yang dilakukan di atas lahan bekas tanaman lama diukur dalam hektar.

\section{METODE PENELITIAN}

Penelitian dikembangkan dengan pendekatan ilmiah melalui proses deduktif dan induktif. Rangkaian dari pendekatan ilmiah demikian adalah mengidentifikasikan permasalahan, menentukan tujuan penelitian, membangun hipotesis, merancang prosedur penelitian, melakukan analisis terhadap data dan informasi, serta menginterpretasikan data dan menarik kesimpulan.

Tempat penelitian adalah desa-desa terpilih atau rumah tangga petani di Kabupaten Musi Banyuasin Provinsi Sumatera Selatan. Wilayah penelitian kabupaten Musi Banyuasin Provinsi Sumatera Selatan dipilih dengan pertimbangan bahwa kabupaten ini dapat mewakili provinsi Sumatera Selatan memiliki luas areal perkebunan karet rakyat terluas di Indonesia yaitu $27.5 \%$ dari total luas areal perkebunan karet rakyat.

Di samping itu Sumatera Selatan merupakan penghasil utama karet di Indonesia yaitu 35,6\% dari total produksi. Sedangkan waktu pene-litian ini akan dilaksanakan mulai bulan Agustus sampai Nopember 2015

Penarikan sampel yang dipakai adalah sampel bertahap (multi stage sampling) dengan quota terhadap kecamatan dan desa. Dari setiap kecamatan dipilih secara sengaja 6 desa sebagai perwakilan dengan kriteria areal karet terluas. Dari setiap desa kemudian diambil sampel secara acak sebanyak 20 sampel petani dari kerangka sampel desa terpilih. Quata sampel petani 
maju dan tradisional $50 \%$ yaitu 60 petani maju dan 60 petani tradisional.

Metode pengumpulan data melalui wawancara langsung dengan petani sampel dan meng-adakan studi pendalaman terhadap hasil pengumpulan data. Wawancara dilakukan mengguna-kan daftar pertanyaan yang berisikan pertanyaan-pertanyaan terbuka dan tertutup yang berkait-an dengan variabel biaya, pendapatan dan tabungan.

Pengolahan data dikumpulkan dari survei diolah mengikuti prosedur untuk pengkajian hipotesis yang telah dirumuskan. Tabulasi data diolah dengan menggunakan program Excel. Pengujian hipotesis dilakukan dengan membandingkan secara diskriptif persentase kemampuan ekonomis petani apabila proporsi (persentase) petani tidak mampu mayoritas (50\%) maka Ho diterima berarti tabungan petani sebagian besar tidak mampu menanggung biaya investasi peremajaan kebun karetnya secara mandiri.

\begin{tabular}{|c|c|c|c|c|c|c|}
\hline \multirow[t]{2}{*}{ No } & \multirow[b]{2}{*}{ Kabupaten } & \multirow{2}{*}{$\begin{array}{l}\text { Total } \\
\text { Pendapatan RT } \\
\text { (Rp.) }\end{array}$} & \multirow{2}{*}{$\begin{array}{l}\text { Pengeluaran RT } \\
\text { (Rp.) }\end{array}$} & \multicolumn{3}{|c|}{ Tabungan Potensial (Rp.) } \\
\hline & & & & Rumah Tangga & Penjualan Kayu Karet & Jumlah \\
\hline 1 & Tradisional & 7.247 .000 & 5.194 .000 & 2.024 .000 & 1.220 .000 & 3.244 .000 \\
\hline 2 & Maju & 8.575 .000 & 5.521 .000 & 3.022 .000 & 1.221 .000 & 4.243 .000 \\
\hline
\end{tabular}

Pada Tabel 1 dapat diketahui bahwa rata-rata potensi tabungan rumah tangga petani maju sebesar $\mathrm{Rp} 3.022 .000$ per tahun lebih besar dari petani tradisional sebesar Rp 2.024.000 per tahun. Bila dihubungkan dengan keharusan petani menabung untuk biaya investasi peremajaan kebun karetnya maka tidak akan mengalami kesulitan karena hanya sekitar $8 \%$ dari tabungan petani per tahun.

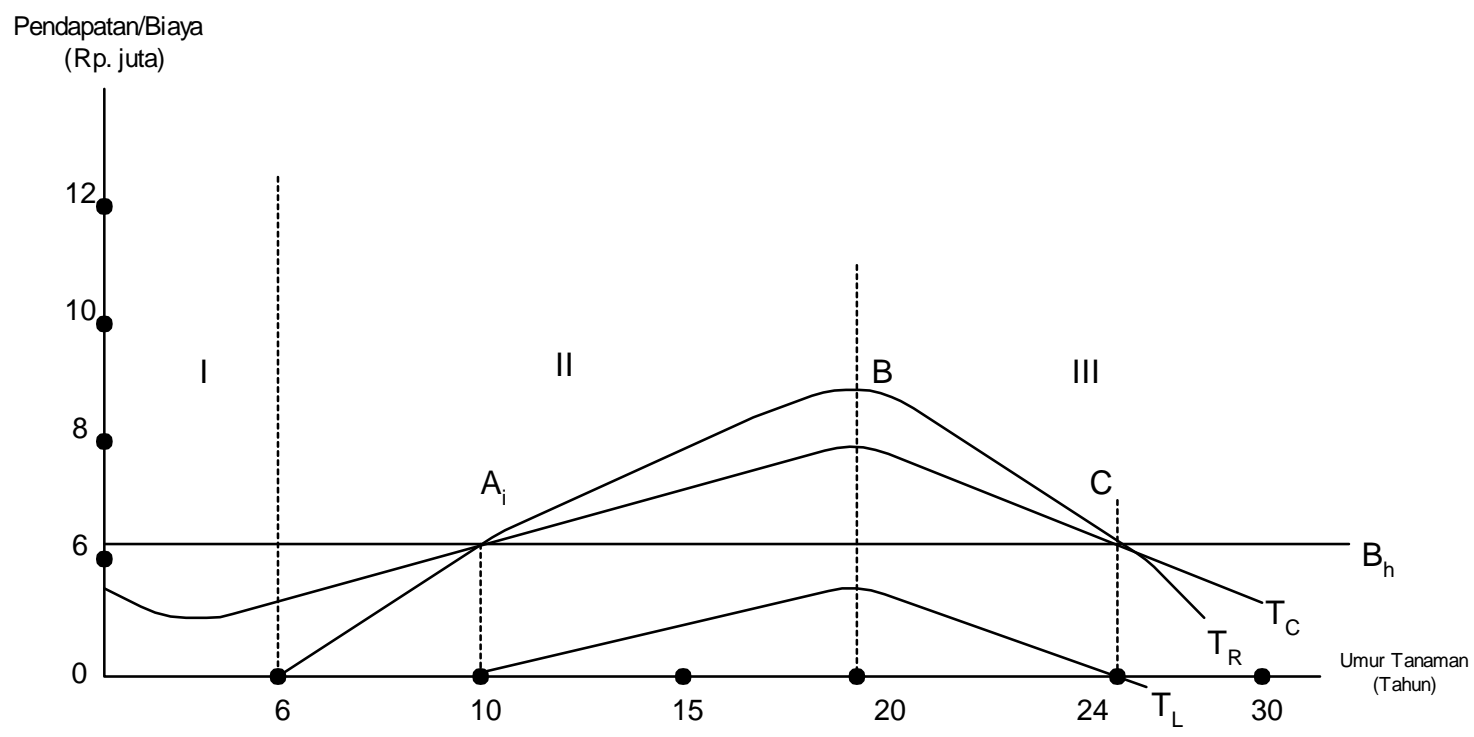


HASIL PENELITIAN DAN

\section{PEMBAHASAN}

\section{Analisis Usahatani Tanaman Karet}

Rata-rata pendapatan, pengeluaran dan potensial tabungan Rumah Tangga petani tradi-sional dan maju di Musi Banyuasin Sumatera Selatan dapat dilihat dari Tabel 1.
Tabel 1. Rata-rata Potensi Tabungan Rumah Tangga Petani Tradisional Dan Maju Tahun 2014

Hubungan umur tanaman karet (Uk) dengan total penerimaan (TR) dan total biaya produksi usahatani petani tradisional (TC) dapat dibuat grafik seperti Gambar 2
Keterangan : I = Tanaman karet belum berproduksi peremajaan)

II = Tanaman karet berproduksi meningkat

III = Tanaman karet berproduksi menurun

$$
\begin{aligned}
& \mathrm{A}=\mathrm{T}_{\mathrm{R}}=\mathrm{T}_{\mathrm{C}} \quad \text { (awal perencanaan } \\
& \mathrm{B}=\mathrm{T}_{\mathrm{R}} \text { tertinggi } \\
& \mathrm{C}=\mathrm{T}_{\mathrm{R}}=\mathrm{T}_{\mathrm{C}} \text { (saat peremajaan) }
\end{aligned}
$$

Gambar 2. Hubungan Umur Tanaman Karet $\left(\mathrm{U}_{\mathrm{k}}\right)$ Dengan Total Penerimaan $\left(\mathrm{T}_{\mathrm{R}}\right)$ Dan Total Biaya Produksi $\left(\mathrm{T}_{\mathrm{C}}\right)$ Usahatani Karet Petani Tradisional Dan Maju.

Pada Gambar 2 terlihat bahwa awal perencanaan peremajaan kebun karet dimulai sejak titik A umur tanaman karet 9 tahun $(\mathrm{TR}=\mathrm{TC}$ ) dan pada umur 28 tahun dimana $(\mathrm{TR}=\mathrm{TC})$ pada saat inilah peremajaan kebun karet sebaiknya dilakukan. Setelah umur ini petani mulai meng-alami kerugian (TR<TC). Dengan asumsi biaya investasi peremajaan kebun karet sebesar Rp 11.252.625,- yang di tabung selama 15 tahun, dan dengan bunga bank komersil 18\% maka dengan menggunakan rumus sinking fund factor dapat diketahui setiap tahun petani tradisional harus menabung Rp 184.600 per tahun dan Rp 170.000 per tahun untuk petani maju.

\section{Pengujian Hipotesa Kemampuan Tabungan Petani}

Adapun kemampuan petani dalam menanggung biaya peremajaan kebun karet petani tra-disional dan maju dapat dilihat pada Tabel 2.

Pada Tabel 5 dapat dijelaskan bahwa jumlah petani tradisional yang tidak mampu me-nanggung biaya peremajaan kebun karetnya sebanyak 36 KK (60\%), sedangkan petani maju yang tergolong tidak mampu menanggung biaya investasi peremajaan kebun karet sekitar $26 \mathrm{KK}$ $(43,89 \%)$, ini berarti bahwa hipotesa untuk petani maju ditolak karena terbukti mayoritas (>60\%) mampu menanggung biaya peremajaan kebun karetnya. Sedangkan petani tradisional hipotesa diterima karena terbukti mayoritas (>50\%) petani tidak mampu menanggung biaya peremajaan kebun karetnya.

Kemampuan petani tradisional melakukan peremajaan sebanyak $11 \mathrm{KK}$ atau $17 \%$ mem-punyai kemampuan peremajaan 36\%-70\% tergolong sedang, artinya kemampuan petani dapat melakukan peremajaan dalam dua tahap atau dua tahun tanam tanpa bantuan kredit perbankan.

Apabila memerlukan bantuan perbankan petani akan memperoleh kredit sebesar 38\%-47\% dari total biaya investasi peremajaan. Petani sebanyak $13 \mathrm{KK}$ atau $23 \%$ mempunyai kemam-puan peremajaan $>70 \%$ tergolong tinggi artinya petani dapat melakukan peremajaan sekaligus dalam 
satu tahun tanam. Apabila petani memerlukan bantuan perbankan hanya membutuhkan biaya investasi peremajaan $25 \%-30 \%$ dari total investasi.

Kemampuan petani maju melakukan peremajaan sebanyak $15 \mathrm{KK}$ atau $25 \%$ mempunyai kemampuan peremajaan 36\%$70 \%$ tergolong sedang artinya kemampuan petani dapat melaku-kan peremajaan dalam dua tahap atau dua tahun tanpa bantuan perbankan bila memerlukan bantuan perbankan petani membutuhkan kredit sebesar $38 \%-47 \%$, petani sebanyak $19 \mathrm{KK}$ atau $31 \%$ mempunyai kemampuan peremajaan tergolong tinggi karena nilai ratio terletak antara $>70 \%$ artinya petani dapat melakukan peremajaan kebun karet secara sekaligus satu tahun tanam.

\section{KESIMPULAN DAN SARAN}

Dari hasil analisis dan pembahasan mengenai analisis kemampuan tabungan petani untuk menanggung biaya peremajaan karetnya dapat di tarik beberapa kesimpulan sebagai berikut :

1. Petani tradisional dan maju yang tidak mampu menanggung biaya peremajaan kebun karetnya masing-masing sebanyak $108 \mathrm{KK}(60 \%)$ dan $79 \mathrm{KK}$ $(43,89 \%)$. Ini berarti bahwa hipotesa kedua ditolak untuk petani maju karena terbukti petani maju mayoritas (>50\%) mampu menanggung biaya peremajaan kebun karetnya. Sedangkan hipotesa kedua di-terima untuk petani tradisional karena terbukti petani tradisional mayoritas $(>50 \%)$ tidak mampu menanggung biaya investasi peremajaan kebun karetnya. Bagi petani yang mampu dapat melaksanakan peremajaan kebun karetnya secara sekaligus atau bertahap.

2. Tabungan rumah tangga petani maju sebesar Rp 3.022.000 per tahun lebih besar dari petani tradisional sebesar Rp 2.024.000 per tahun. Bila dihubungkan dengan keharusan petani tradisional dan maju menabung sebesar Rp 184.600 per tahun dan Rp 170.000 per tahun selama 15 tahun yaitu mulai umur 9 tahun sampai dengan umur ekonomis 24 tahun pembiayaan investasi peremajaan kebun karetnya, maka tidak akan mengalami kesulitan karena hanya sekitar $8 \%$ dari tabungan petani per tahun.

Dalam upaya pemberdayaan ekonomi rumah tangga petani yang berkelanjutan diperlukan kebijakan :

1. Pengembangan diversifikasi usaha dan penggunaan tenaga kerja keluarga petani sebagai sumber pendapatan terbaik bagi rumah tangga petani melalui pemanfaatan waktu luang untuk kegiatan di luar usahatani. Peningkatan kemampuan teknis petani karet dan peningkatan produktivitas sesuai dengan potensi melalui upaya penggunaan bibit unggul dan anjuran atau rekomendasi teknis instansi terkait.

2. Pemberian bantuan pinjaman modal untuk pengadaan paket teknologi anjuran melalui kredit dengan jaminan sertifikat lahan kebun. Penyuluhan dan pembinaan kelembagaan keuangan petani untuk menghimpun dana tabungan potensial guna meningkatkan ke-mampuan ekonomis petani untuk menanggung biaya investasi peremajaan kebun karetnya saat umur ekonomis. Kebijakan makro 
pembangunan ekonomi yang berpihak kepada pe-tani berkenaan dengan kebijakan perdagangan, harga, fiskal, moneter dan penanaman modal.

\section{DAFTAR PUSTAKA}

Dinas Perkebunan Provinsi Sumatera Selatan, 2012. Laporan Tahunan Dinas Perkebunan Provinsi Sumatera Selatan Tahun 2012, Palembang.

Rifai. N, 2000. Determinan Potensi Peningkatan Produksi Bokar Petani Peserta TCSDP Di Kabupaten Muara Enim Provinsi Sumatera Selatan. Tesis S2 UNSRI (tidak diterbitkan)

Supriadi. M., C. Nancy dan G. Wibawa, 1999. Percepatan Peremajaan Karet Rakyat Melalui Penerapan Teknologi Dan Kegiatan Pemberdayaan Masyarakat Perkebunan. Lokakarya Ekspose Teknologi Perkebunan. Palembang : 45-69.

Supriadi, M., C. Nancy, M. Jahidin. R, G. Wibawa, K. Amypalupy, 2001.
Laporan Akhir Studi Karakteristik Sosial Ekonomi Peremajaan Karet Rakyat Partisipatif Di Kecamatan Sungai Keruh Dan Babat Toman Kabupaten Musi Banyuasin Sumatera Selatan, Kerjasama Pemerintah Daerah Musi Banyuasin Dan Balai Penelitian Karet Sembawa.

Supriadi, M. dan C. Nancy, 2001. Percepatan Adopsi Teknologi Karet Pada Perkebunan Karet Rakyat. Proc IRRDB Symp. 2000 : 385-398.

Supriadi. M. dan C. Nancy, 2004. Partisipatory Rubber Replanting Model. Its Progress of Implementation In Indonesia Rubber Smallholding Sector. Sembawa Research Station.

Wargadipura. R, 1978. Tehnik Penanaman Ulang Pada Perkebunan Karet. Menara Perkebunan 46 : 123 - 130. 